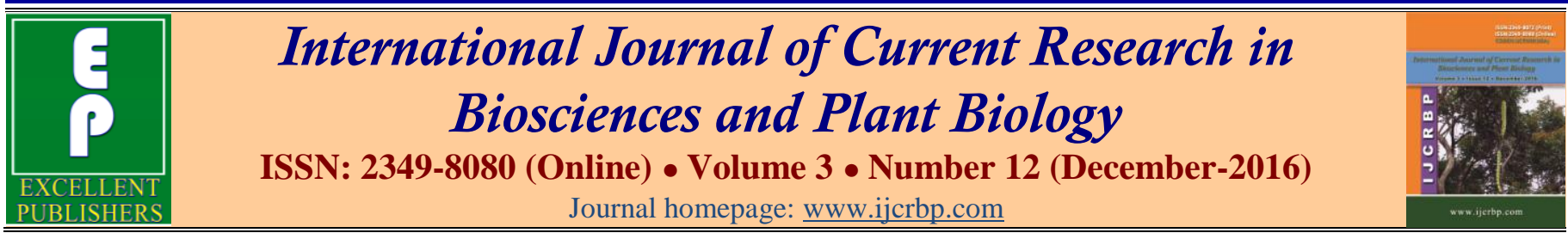

Review Article

doi: http://dx.doi.org/10.20546/ijcrbp.2016.312.013

\title{
Arsenic and It's Adjuvantic Role on Oxidative Stress in Animals: A Brief Overview
}

\author{
Arup Giri, Vijay K. Bharti*, Kunzes Angmo, Sahil Kalia, Prince Vivek and Bhuvnesh Kumar
}

Animal Science Division, Defence Institute of High Altitude Research (DIHAR), DRDO, Leh-Ladakh, Jammu \& Kashmir, India

*Corresponding author.

\begin{abstract}
A b stract
Arsenic (As) exposure is a global public health problem because of its association with various cancers and numerous other pathological effects, and millions of people worldwide are exposed to As on a regular basis mainly through drinking water. Increasing lines of evidence indicate that As may adversely affect the antioxidant defense system, but its specific mechanism to abrupt the antioxidant defense system are poorly understood. Therefore, we conducted a literature search of As and its oxidative stress-related effects associated with As exposure and summarized the known oxidative disorders of As in humans and laboratory animals. Overall, the review indicates that chronic exposure to As has the potential to impair the antioxidant system which could lead to increased risk of disorders and chronic diseases, including various cancers. Further investigation, particularly in humans, is needed to better understand the relationship between As exposure and the development of disease as well as the proper mechanism.
\end{abstract}

\section{Article Info}

Accepted: 01 December 2016

Available Online: 06 December 2016

\section{Keywords}

Acute exposure

Antioxidant defense system

Chronic exposure

Inorganic and organic arsenic

Oxidative molecules

Oxidative stress

\section{Introduction}

Most of the world has been polluted due to the contaminated toxic effects of Arsenic (As). It is mobile in nature. From the rocks due to weathering it has been released to the environment and dissolute to the environment (Flora et al., 2005; Mandal and Suzuki, 2002). Chronic exposure to inorganic arsenic can lead deterioration of several organs in the body after resulting of cancer (Aposhian et al., 2003). With different chemical forms it has different types of toxicity depending on its doses also. Mostly, inorganic and organic forms are abundant and among them inorganic forms has most deleterious effects (Geiszinger et al., 2002; Fattorini and Regoli, 2004). Among the other arsenic species, moderately toxicity has been showed by trimethyl-arsine oxide (TMAO) and tetra- methylarsonium (TETRA). Meanwhile, arsenobetaine (AsB), arsenocholine (AsC) and other arsenosugars (AsS) show no toxicity (Fattorini et al., 2006). Arsenic caused the imbalance between pro-oxidant and anti-oxidant which ultimately showed the oxidative stress (Shila et al., 2005). Moreover, due to presence of differences in the chemical form, it has has many differences between arsenite and arsenate effects (Tseng, 2004). Because of its similar biochemical properties to phosphate, arsenate integrated with the phosphorylation reactions (Fattorini and Regoli, 2004) and has the biochemical properties to sulfydryl groups, which can induce structural modification in proteins, leading to the inactivation of many enzymes (Akter et al., 2005). Inorganic arsenic has been classified as a known human carcinogen (IRIS, 
1997) and its chronic exposure can lead to cancer of the skin, lungs, bladder, liver (IARC, 2012). It also exerts neurological disorders, muscular weakness, loss of appetite, and nausea (Mandal and Suzuki, 2002). Arsenic (As) has the effectiveness of the apoptotic pathways. Through which severe oxidative stress has been arise (Tokar, 2011). Arsenic mainly hampered the balance of pro-oxidant and antioxidant homeostasis; ultimately caused oxidative stress (Shila et al., 2005). Taking into account the studies cited above, the objective of the present review is to analyze and to update information about arsenic and toxicity in animals due to As induced oxidative stress.

\section{An overview of arsenic (As)}

Sources of arsenic in the environment: Arsenic (As) is a naturally occurring and wide spread pollutant in various regions of the world with its both metalloid and non metalloid properties (Flora et al., 2005). Arsenic and its compounds have showed the mobile nature in environment. Arsenic sulfides to arsenic trioxide have been converted due to the weathering process of rocks. These compounds then entered in the environment through dust, rain, river water or groundwater, etc. (Mandal and Suzuki, 2002). Arsenic can be found in rock, soil, water, air and the earth biosphere. There are many forms or species of arsenic and these can be broadly categorized as inorganic or organic (EFSA, 2009). Arsenic is also found in surface rocks and minerals, where it may be combined with sulfur and/or metals, including manganese, iron, cobalt, tin, silver, and nickel often as a complex oxide (Waugh, 1982).

\section{Chemical characteristics of As}

Arsenic: atomic number 33 is ranking $20^{\text {th }}$ in natural abundance, comprising about $0.00005 \%$ of the earth's crust, $14^{\text {th }}$ in the seawater, and $12^{\text {th }}$ in the human body (Mandal and Suzuki, 2002). It's concentration in most rocks ranges from 0.5 to $2.5 \mathrm{mg} / \mathrm{kg}$, though higher concentrations are found in finer grained argillaceous sediments and phosphorites (Mandal and Suzuki, 2002). It is a silver-grey brittle crystalline solid with atomic weight 74.9 ; specific gravity 5.73 , melting point $817^{\circ} \mathrm{C}$ (at $28 \mathrm{~atm}$ ), boiling point $613^{\circ} \mathrm{C}$ and vapor pressure $1 \mathrm{~mm}$ $\mathrm{Hg}$ at $372^{\circ} \mathrm{C}$. It was isolated in 1250 a.d. by Albertus Magnus (Mandal and Suzuki, 2002).

\section{Types of As}

Arsenic exists in the $-3,0,+3$ and +5 oxidation states
(Smedley and Kinniburgh, 2002). There are many forms, or species, of arsenic and these can be broadly categorized as inorganic or organic (Aronson, 1994). Two forms are common in natural waters: arsenite $\left(\mathrm{AsO}_{3}{ }^{3-}\right)$ and arsenate $\left(\mathrm{AsO}_{4}{ }^{3-}\right)$, referred to as arsenic (III) and arsenic (V). Pentavalent $(+5)$ or arsenate species are $\mathrm{AsO}_{4}{ }^{3-}, \mathrm{HAsO}_{4}{ }^{2-}, \mathrm{H}_{2} \mathrm{AsO}_{4}{ }^{-}$while trivalent $(+3)$ arsenates include $\mathrm{As}(\mathrm{OH})^{3}, \mathrm{As}(\mathrm{OH})^{4-}, \mathrm{AsO}_{2} \mathrm{OH}^{2-}$ and $\mathrm{AsO}_{3}{ }^{3-}$. Pentavalent species predominate and are stable in oxygen rich aerobic environments.

Trivalent arsenites predominate in moderately reducing anaerobic environments such as groundwater (EFSA, 2009). While methylated forms (methylarsonate, MMA and dimethyl arsinate, DMA) are considered only moderately toxic (Fattoriniand Regoli, 2004). Other arsenic species, like trimethyl-arsineoxide (TMAO) and tetra- methyl-arsonium (TETRA) are also considered moderately toxic, whereas arsenobetaine (AsB), arsenocholine (AsC) and other arseno sugars (AsS) show no toxicity (Fattorini et al., 2006). Environmental forms include arsenious acids $\left(\mathrm{H}_{3} \mathrm{AsO}_{3}, \mathrm{H} 3 \mathrm{AsO}_{3}, \mathrm{H}_{3} \mathrm{AsO}_{3}{ }^{2-}\right)$, arsenic acids $\left(\mathrm{H}_{3} \mathrm{AsO}_{4}, \mathrm{H}_{3} \mathrm{AsO}_{4}{ }^{-}, \mathrm{H}_{3} \mathrm{AsO}_{4}{ }^{2-}\right)$, arsenites, arsenates, methylarsenic acid, dimethylarsinic acid, arsine, etc. Arsenic (III) is hard acidic in nature which and preferably chelates with oxides and nitrogen. Whereas, arsenic which has the valences with (V) shows soft acidic nature and has the great tendency to form complexes with sulfides (Bodek, 1998).

\section{Metabolism of As in animal body}

The main inorganic forms of arsenic relevant for human exposures are pentavalent arsenic (also called arsenate, As $(\mathrm{V})$, or $\mathrm{As}^{+5}$ ) and trivalent arsenic (also called arsenite, As (III), or $\mathrm{As}^{+3}$ ). These inorganic species undergoes a series of reduction and oxidative/methylation steps in human liver and other tissues to form tri- and pentavalent methylated metabolites of methylarsonite [MA(III)], methylarsonate $[\mathrm{MA}(\mathrm{V})]$, dimethylarsinite [DMA(III)], and dimethylarsinate $[\mathrm{DMA}(\mathrm{V})]$.

Some mammalian species also produce trimethylated metabolites, trimethylarsine oxide [TMA (V)O] and, possibly, the volatile trimethylarsine [TMAs(III)] . Fish and other seafood are the major sources of exposure to organic arsenic, in the form of arsenobetaine, arsenosugars, and arsenolipids. The distinction between inorganic and organic forms is important because it is generally accepted that the organic species are excreted more quickly from the body and generally considered less toxic, with a relative rank order of $\mathrm{As}(\mathrm{III})>\mathrm{As}(\mathrm{V})>>$ 
MA(V), DMA(V) > arsenobetaine. However, the methylated trivalent metabolites, MA(III) and DMA(III), are significantly more toxic than their pentavalent counterpart and either $\mathrm{As}(\mathrm{III})$ or $\mathrm{As}(\mathrm{V})$ (Akter et al., 2005). Inorganic arsenic is metabolized by a sequential process and described by Vahter (1994) as below (Fig. 1):

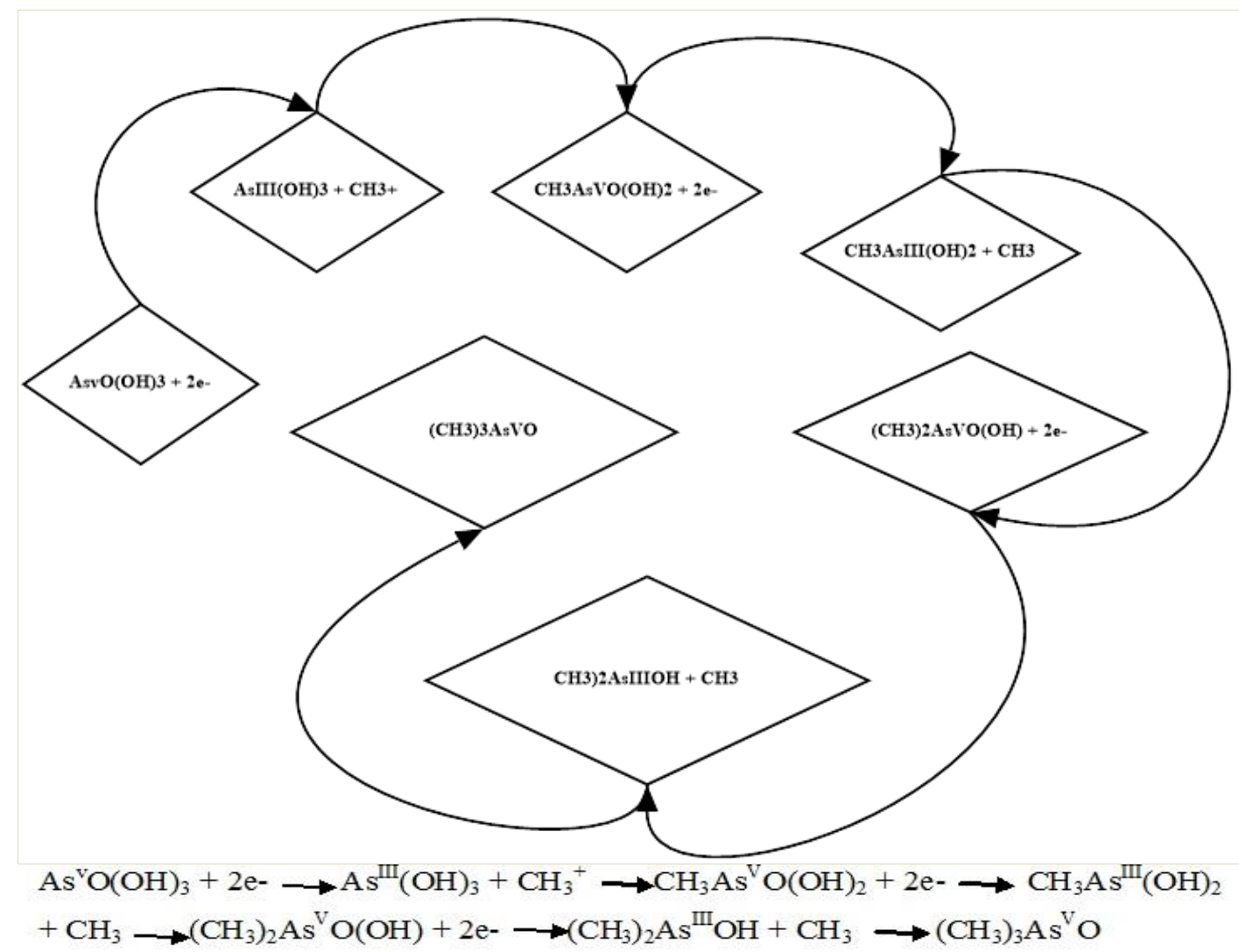

Fig. 1: Inorganic arsenic metabolism by a sequential process (Source: Vahter, 1994).

\section{Biotransformation of As}

In drinking water, As is normally found as $\mathrm{As}^{\mathrm{V}}$. After the consumption by humans and other organisms it rapidly undergoes metabolic conversion. This metabolic conversion called as biotransformation (Sakurai et al., 2005). Through this process, at first, the arsenate is converted into arsenite and then subsequently transformed into mono-, di-, and trimethylated products (Thomas et al., 2004). These reactions show that As methylation is associated with reduction of $\mathrm{As}^{\mathrm{V}}$ to $\mathrm{As}^{\mathrm{III}}$ (Thomas et al., 2004). As a reducing agent, antioxidant glutathione (GSH) plays an important role in arsenic biotransformation. GSH convert As to it's trivalency and formed arsenotriglutathione [As $\left.{ }^{\text {III }}(\mathrm{GS})_{3}\right]$. In this complex, As ${ }^{\text {III }}$ is joind to the thiol groups of the cysteinyl residues of three GSH molecules (Kobayashi et al., 2005; Thomas et al., 2001). Mainly, reduction reaction of arsenate to arsenite catalyzed by anarsenate reductase enzyme. This process requires the presence of inosineandathiol compound (Aposhian et al., 2004).
Aarsenite is methylated by arsenite methyltransferase in mammals (Akter et al., 2005). One of the in-vitro study on rat liver, exposed with arsenite and methylarsonous diiodide $\left(\mathrm{CH}_{3} \mathrm{As}^{\mathrm{IIII}}{ }_{2}\right)$ demonstrated that arsenite was the preferred substrate for the ethylation reaction. The reduction conversion reaction of arsenite to methylated metabolites being faster than for arsenate. For the arsenic methylation, a donor of methyl groups must be present at the time of reduction conversion reaction. Studies, both on, in vitro and in vivo with the mammal models have been identified that S-adenosylmethionine (AdoMet) act as the methyl group donor (Thomas et al., 2004; Thomas et al., 2001). The enzyme methyl arsonate reductase catalyzes the reduction of monomethylarsonate $\left(\mathrm{MMA}^{\mathrm{v}}\right)$, dimethylarsonate $\left(\mathrm{DMA}^{\mathrm{V}}\right)$ and arsenate $\left(\mathrm{As}^{\mathrm{V}}\right)$ to monomethyl arsonous acid (MMA ${ }^{\mathrm{III}}$ ), dimethyl arsonous acid $\left(\mathrm{DMA}^{\mathrm{III}}\right)$ and arsenite $\left(\mathrm{As}^{\mathrm{III}}\right)$, respectively. The activity of this enzyme is the rate-limiting step for inorganic arsenic methylation. Methyl arsonate reductase has an absolute requirement for GSH, being recognized as the omegaiso form of the enzyme glutathione-S- 
transferase (GST) (Zakharyan et al., 1999; Aposhian et al., 2004). GST families are multifunctional molecules. This plays a key role in cellular detoxification. This family of enzyme, is the rate-limiting enzyme for biotransformation of inorganic arsenic (Townsend and Tew, 2003; Sampayo- Reyes and Zakharyan, 2006).

\section{Effect of As throughout globe}

Worldwide billions of people are obligated to consume the drinking water with higher arsenic level than the prescribed level of World Health Organization (WHO). Now a day, it is the worldwide problem of As contaminated natural water consumption. Most of the countries like USA, China, Chile, Bangladesh, Taiwan, Mexico, Argentina, Poland, Canada, Hungary, New Zealand, Japan and India has been reported with As contamination. In the area of Indo-Bangladesh region, about 70 million people are suffering from As contaminated drinking water consumption (Karim, 2000; Hassan et al., 2003).

According to Peters et al. (2000) in New Hampshire, USA, inorganic arsenic was present in about $95 \%$ sample of drinking water. In these sample, the level of As lied within the range of $0.01 \mu \mathrm{g} / 1$ to $180 \mu \mathrm{g} / \mathrm{l}$. In Argentina, the concentration of arsenic in groundwater ranged from $100 \mu \mathrm{g} / 1$ to $2000 \mu \mathrm{g} / \mathrm{l}$. In this country about 200,000 people are consume the contaminated water (British Geological Survey, 2001). In case of Romania and Hungary, about 4,00,000 population used drinking water above minimum concentration level (MCL). The range of arsenic concentration was 2 to $176 \mu \mathrm{g} / \mathrm{l}$ (WHO, 2003). After the study of Smith et al. (2000), in Chile, it was found that the range of arsenic level in drinking water was 750 to $800 \mu \mathrm{g} / 1$.

In China, the concentration of arsenic in well water in the affected areas was $50 \mu \mathrm{g} / \mathrm{l}$ to $2000 \mu \mathrm{g} / 1$ and about 2 million people in the affected area use the drinking well water containing arsenite more than common standard, which cause Raynaud's disease in the population (Xia and Liu, 2004). In Taiwan, the arsenic concentration in well water used for drinking purpose were $10-1800 \mu \mathrm{g} / 1$ and a peripheral vesicular disease called "Black foot disease" is a common disease among the living population due to arsenicism (Lamm et al., 2006).

Report of British Geological Survey (2001) informed that in Bangladesh, more than 70-80 million people are at a risk of drinking contaminated water. The drinking water arsenic levels were ranged from non-detectable to $4700 \mu \mathrm{g} / \mathrm{l}$. West Bengal (India) and Bangladesh are the worst affected areas in the world from arsenicism. The standard of most developing countries is $50 \mu \mathrm{g} / \mathrm{l}$, which is several times higher than the MCL and more hazardous to the population.

The study of Acharya (2002) stated that in West Bengal (India), the arsenic concentration in drinking water is about 60 to $3700 \mu \mathrm{g} / \mathrm{l}$. About 40 million people are affected from this reason. Another study of Chakraborti et al. (2003), demonstrated that in middle Ganga plain, Bihar, 206 tube wells (95\% of total) were analyzed for arsenic content and showed that $56.8 \%$ tube wells have exceeded arsenic concentration of $50 \mu \mathrm{g} / 1$ and $19.9 \%$ have more than 300 $\mu \mathrm{g} / \mathrm{l}$. The maximum permissible limits for drinking water in different countries are given in the Table 1.

Table 1. The maximum permissible limits for drinking water in different countries.

\begin{tabular}{llll}
\hline Sl. No. & Sources & Name of the country & Maximum permissible limit (mg/l) \\
\hline 1. & Bhattacharya et al. (2006) & Argentina & 50 \\
2. & Kinniburgh and Smedley (2001) & Bangladesh & 50 \\
3. & Mandal and Suzuki (2002) & China & 50 \\
4. & Sancha (2000) & Chile & 50 \\
5. & Dhar et al. (1997) & India & 10 \\
6. & Wyatt et al. (1998) & Mexico & 50 \\
7. & Shrestha et al. (2003) & Nepal & 50 \\
8. & Aggett and Kriegman (1988) & New Zealand & 10 \\
9. & Tseng et al. (2005) & Taiwan & 10 \\
10. & Oremland et al. (2004) & USA & 10 \\
11. & Agusa et al. (2006) & Vietnam & 10 \\
\hline
\end{tabular}

\section{As exposure and effects on health}

One report of IARC (2012) stated that, in India, Bangladesh, Taiwan, Chile, and the United States about
100 million people worldwide are exposed to As, particularly through ingestion of contaminated food and water exposures also occur through inhalation, especially in agricultural and industrial settings (Nordstrom, 2002). 
Human population is mostly exposed to arsenic through ingestion, inhalation and dermal contact. Chen et al. (2004) reported that world population are exposed to arsenic through contaminated water, foods, drugs, wines, smoke of cigarette and fossil fuels. In case of occupational exposure, through industrial exposure, the workers are exposed to airborne arsenic (USPHS, 1989). At the time of treating some disease like syphilis, asthma, rheumatism, cough, pruritus and itching, arsenic contamination has been occurred (Ko, 1999). To treat advanced trypanosomiasis and acute promyelocytic leukemia (APL), pentavalent arsenic is used (Novick and Warrell, 2000). Inorganic As exists in the environment as arsenite (As) or arsenate (As) and is metabolized in humans via conversion of arsenite to arsanate with subsequent methylation to mono- and di-methylated arsenicals (MMA and DMA, respectively) (Drobna, 2005). MMA is considered the most toxic arsenical in vitro (Petrick, 2001) and individuals who excrete a higher proportion of ingested As as urinary MMA have increased risks of Asassociated cancers (Steinmau et al, 2006), suggesting a key role for MMA in As toxicity. In addition, inorganic arsenic has been classified as a known human carcinogen (IRIS, 1997). Acute exposures to large doses of inorganic arsenic may be fatal. Several studies showed that, for humans, the lethal dose of orally administered arsenic trioxide has been variously estimated as 70 to $180 \mathrm{mg}, 200$ to $300 \mathrm{mg}$ ( 1 to $5 \mathrm{mg} / \mathrm{kg}$ for adults weighing $60-75 \mathrm{~kg}$; (Winship, 1984). But, survival has been reported after doses as high as $10 \mathrm{~g}$ (Winship, 1984). After lower, repeated doses (e.g., 4 to $15 \mathrm{mg} \mathrm{As/d;} \mathrm{(Winship,} \mathrm{1984),}$ arsenicals can elicit effects on the nervous, gastrointestinal, and integumentary systems. Chronic exposure to inorganic arsenic can lead to cancer of the skin (hyperpigmentation, hyperkeratosis and hypopigmentation), lungs, bladder and liver (Yeh et al., 1968; Cebrian et al., 1983; Aposhian et al., 2004; IARC, 2012) as well as neurological disorders, muscular weakness, loss of appetite, and nausea. Through acute poisoning of As, oesophageal and abdominal pain, vomiting and diarrhea has occurred (Duker, 2005). There are several proposed mechanisms of toxicity include imbalance between pro-oxidant and antioxidant homeostasis that results in oxidative stress. Oxidative stress occurred due to the inhibition of genetic expression in the cell (Shila et al., 2005; Flora, 2011; IARC, 2004; Tokar, 2011).

\section{Oxidative stress}

The natural antioxidant defence mechanisms saturate due to the excess production of highly reactive molecules such as reactive oxygen species (ROS) and reactive nitrogen species (RNS) (Maritim, 2003). Most widely studied examples of ROS are superoxide $\left(\cdot \mathrm{O}_{2}{ }^{-}\right)$, hydroxyl ion $(\cdot \mathrm{OH})$ and hydrogen peroxide $\left(\mathrm{H}_{2} \mathrm{O}_{2}\right)$ (Evans, 2002). Common RNS include nitric oxide $(\cdot \mathrm{NO})$ and peroxynitrite $\left(\mathrm{ONOO}^{-}\right)$(Evans, 2002). Oxidative stress induced by oxidant species occurs under conditions when antioxidant defence is attenuated or when the rate constants of the radical reactions are greater than the antioxidant defence mechanisms (Fig. 2; Buettner, 1993).

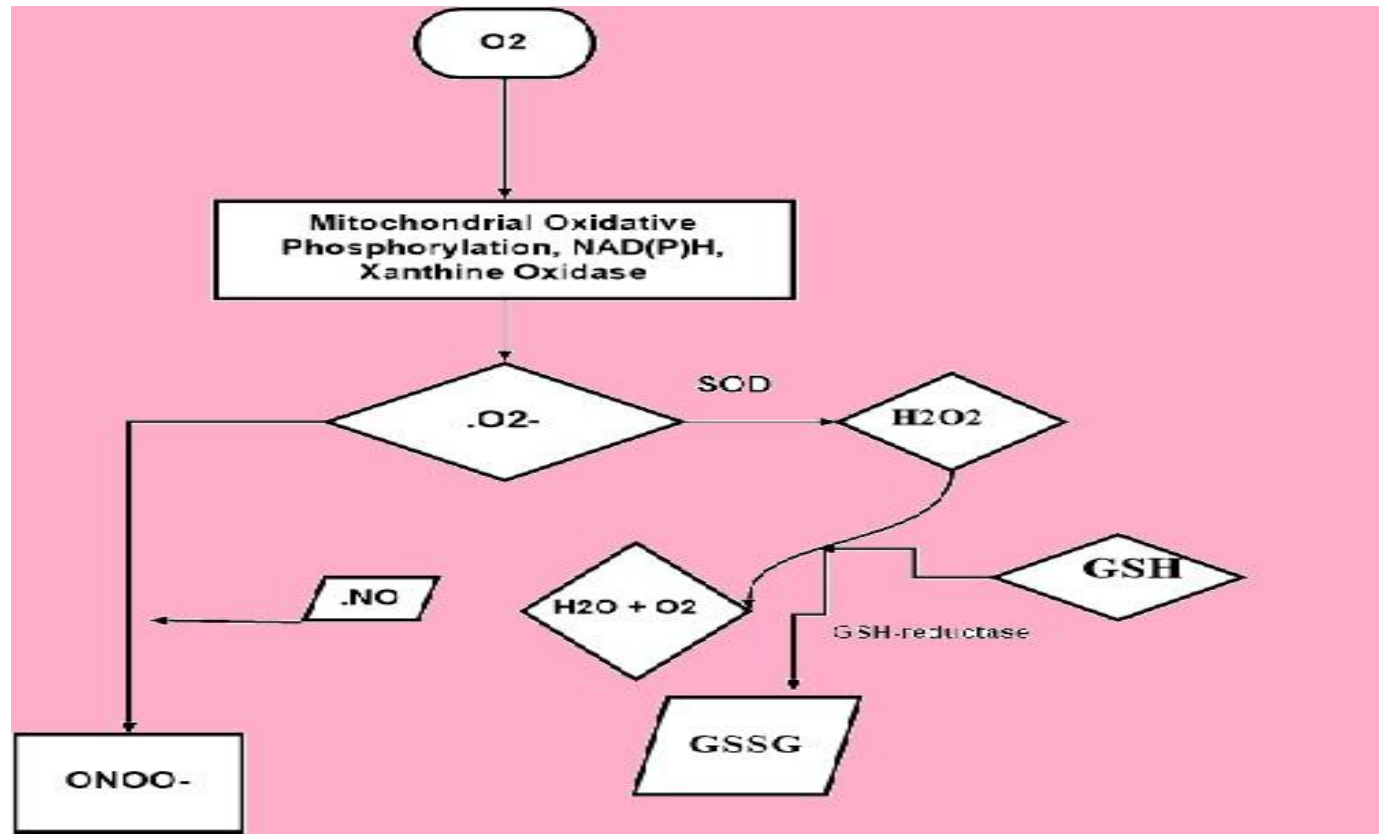

Fig. 2: Oxidative stress induced by oxidant species (Source: Buettner, 1993). 


\section{Source of oxidative molecules}

\section{Non enzymatic sources}

Fenton's and Haber's reactions: Fridovich (1984) explain the reduction of molecular oxygen to form superoxide anions. These superoxide anions have the ability to form excess and highly reactive oxygen species. The dismutation of superoxides forms hydrogen peroxide $\left(\mathrm{H}_{2} \mathrm{O}_{2}\right)$.

$$
\mathrm{O}^{-2}+\mathrm{O}^{-2 .}+2 \mathrm{H}=\mathrm{H}_{2} \mathrm{O}_{2}+\mathrm{O}_{2}
$$

Hydrogen peroxide is more stable than $\mathrm{O}^{2-}$ superoxide. It is permeable to plasma membrane and plays two important roles in the body. If it is not scavenged by catalase/GSH (glutathione peroxidase) enzyme defence system then it will occurred highly reactive oxygen species (Halliwell and Gutteridge, 1989). Produced hydrogen peroxides react with metal iron or copper to form more highly reactive hydroxyl ions $\left(\mathrm{OH}^{-}\right)$through Fenton's reaction.

$$
\mathrm{Fe}^{2+}+\mathrm{H}_{2} \mathrm{O}_{2}=\mathrm{Fe}^{3+}+\mathrm{OH}^{-}+\mathrm{OH}
$$

Through Haber-Weiss reaction

$$
\mathrm{O}_{2}+\mathrm{H}_{2} \mathrm{O}_{2} \rightarrow \mathrm{O}_{2}+\mathrm{OH}^{-}+\mathrm{OH}^{-}
$$

$\mathrm{H}_{2} \mathrm{O}_{2}$ reacts with $\mathrm{Cl}^{-}$, $\mathrm{Br}^{-}, \mathrm{I}^{-}$and is utilized by myloperoxidase to form more reactive hypochloric acid/hyperchlorite. This is important for protein aggregation and fermentation (Babior, 2000).

\section{Enzymatic sources}

ROS are generated by oxygen metabolism. They have single unpaired electron in their outer orbit which caused them to become highly reactive. It is produced in all aerobic organisms to perform cellular metabolisms. Xanthine oxidases, cyclo-oxygenases (COX) and lipoxygenases (LOX), NO synthases (nitric oxide synthase) and mitochondrial oxidases are the main enzymes for the source of ROS (Lambeth, 2004). As well as, monoamine oxidase, NADPH oxidase/Respiratory Burst Oxidase (RBO), xanthine oxidoreductase, cytochrome $\mathrm{P}_{450}$ oxidase, myelo peroxidase are responsible for the production of oxidative molecules (Cadenas, 2000; El-Benna, 2005; Judge, 2004; Ivanov, 2005; Klebanoff, 2005).

\section{Generation of ROS in cells}

Mitochondria, endoplasmic reticulum (ER) and phagocytic cells (neutrophils and other phagocytes) are the major sites for the production of oxidative molecules in the cell (Tatoyan, 1998; Bedard, 2007; Ghosh, 1997).

\section{Other sources}

Apoptosis, auto-oxidation of small molecules, peroxisomes and lysosomes are also responsible for the several type of oxidative molecules production (Kam, 2000; Freeman, 1982; Tolbert, 1981; Klebanoff, 2005).

\section{Arsenic and oxidative stress}

Oxidative stress is a relatively new theory of arsenic toxicity (Kitchin, 2001). Recent studies have also indicated that arsenic exerts toxicity by generating reactive oxygen species, but the mechanism is still unclear (Chang et al., 2007). Arsenic generates ROS and free radicals like hydrogen peroxide $\left(\mathrm{H}_{2} \mathrm{O}_{2}\right)$, hydroxyl radicals species ( $\mathrm{HO}-)$, nitric oxide $\left(\mathrm{NO}^{-}\right)$, superoxide anion $\left(\mathrm{O}_{2}^{-}\right)$, dimethyl arsinic peroxyl radical $\left[\left(\mathrm{CH}_{3}\right)_{2}\right.$ AsOO- $]$, and dimethyl arsenic radical $\left[\left(\mathrm{CH}_{3}\right)_{2} \mathrm{As}^{-}\right]$ (Yamanaka et al., 1997; Chen et al., 1998; Gurr et al., 1998; Lynn et al., 2000). Since about 1990, there is the proposal that all of these reactive species are responsible for the stress response elicited by arsenicals. However, the mechanism for the production of this reactive intermediate is still not fully understood. But, Yamanaka et al. (1997) proposed the formation of intermediary arsenic species.

Dimethylarsine, a trivalent arsenic form, is a minor in vivo metabolite of DMA which is a pentavalent arsenic form; produced by a process of reduction in the in vivo condition. This can react with molecular oxygen form a $\left(\mathrm{CH}_{3}\right)_{2} \mathrm{As}$ radicals and superoxide anions. Subsequently, $\left(\mathrm{CH}_{3}\right)_{2} \mathrm{As}$ can add another molecule of molecular oxygen and form the $\left(\mathrm{CH}_{3}\right)_{2} \mathrm{AsO}^{-}$radical. Exposure to these free radicals can lead to DNA damage (single strand breaks), (Yamanake and Okada, 1994; Kitchin, 2001). Arsenic also reduces antioxidant levels in plasma, which may accelerate disease development at target site. These reports suggested that intracellular peroxide level is correlated with arsenic induced cellular apoptosis (Hsueh et al., 1998). Ito et al. (1998) reported that GSH has the important protective role against arsenic induced oxidative damage in the cell. Ramos et al. (1995) also described lipid peroxidation as one of the mechanisms of arsenic toxicity in female rats.

Arsenic caused subsequent decrease in cellular GSH concentration. Mainly in the liver, this is inversely 
correlated with lipid peroxidation but not in other tissues (Santra et al., 1999). The functions of glutathione related enzymes like glutathione peroxidase (GPx) and glutathione reductase has either directly or indirectly role as the antioxidant. In case of glutathione-S transferase (GST), it plays the important role in metabolic detoxification. Oxidative stress can be involved in initiation, promotion, or progression of several disorders (Guyton and Kensler, 1993).

In humans, absorbed inorganic arsenic (pentavalent) is biotransformed to trivalent arsenic. Trivalent form of arsenic undergoes methylation to form less toxic compounds. This are excreted in urine but some inorganic arsenic is excreted in the urine unchanged (Hall, 2002). These forms of Arsenic can attenuate various enzymatic action including glycolysis and TCA cycle by binding to sulfhydryl groups of enzymes. Aarsenic compound (pentavalent) has the great role on uncoupling the mitochondrial oxidative phosphorylation. Inhalation exposure to arsenic is associated with an increased risk of lung cancer. The lung is one of the major organs that are affected by arsenic (Kitchin, 2001). Oxidative stress theory for arsenic carcinogenicity can be partially explained by its ability to cause cancer at high rates in the lung, bladder and skin. In case of human lung, it may be an organ responsive to arsenic carcinogenesis because of high partial pressure of oxygen and the fact that dimethylarsine a gas excreted via the lungs (Yamanaka and Okada, 1994). However, oxidative stress has been widely accepted as a general mechanism of action for cellular injury and toxic effects of arsenic (Del Razo et al., 2001).

\section{Conclusion}

Arsenic exposure can affect millions of people worldwide. Through different types of exposure it exposed to animals and caused severe types of different disorders in the animal body. Arsenic can affect the mammalian body by inducing the oxidative stress and cause of different diseases. Arsenic is a main agent of misbalancing between the generation of oxidative molecules and antioxidant defense system. Ultimately, it caused cancer in different organs of the body and as well as cause of cardiovascular disease, skin lesions, urinary disorder, metabolic disorders, etc. However, we are aware about the arsenic as a causal agent of oxidative stress but its proper mechanism yet to be known. To provide a deeper understanding of the pathology of arsenic induced oxidative stress diseases and the toxicology of arsenic in various organs, further research is necessary.

\section{Conflict of interest statement}

Authors declare that they have no conflict of interest.

\section{References}

Acharyya, S. K., 2002. Arsenic contamination in ground water affecting major part of the southern West Bengal and parts of Western Chhattisgarh: Source and mobilization process. Curr Sci. 82, 740-744.

Aggett, J., Kriegman, M. R., 1988. The extent of formation of arsenic (III) in sediment interstitial waters and its release to hypolimnetic waters in Lake Ohakuri. Water Res. 22, 407-411.

Agusa, T., Kunito, T., Fujihara, J., Kubota, R., Minh, T. B., Trang, P. T. K., Iwata, H., Subramanian, A., Viet, P. H., Tanabe, S., 2006. Contamination by arsenic and other trace elements in tube-well water and its risk assessment to humans in Hanoi. Vietnam Environ Pollut. 139, 95106.

Akter, K. F., Owens, G., Davey, D. E., Naidu, R., 2005. Arsenic speciation and toxicity in biological systems. Rev. Environ. Contam. Toxicol. 184, 97-149.

Aposhian, H. V., Zakharyan, R. A., Avran, M. D., SampayoReyes, A., Wollenberg, M. L., 2004. A review of the enzymology of arsenic metabolism and new potential role of hydrogen peroxide in the detoxication of the trivalent arsenic species. Toxicol. Appl. Pharmacol. 198, 97-149.

Aronson, S. M., 1994. Arsenic and old myths. R I Med. 77, 233-244.

Babior, B. M., 2000. Phagocytes and oxidative stress. Am. J. Med. 109, 33-44.

Bedard, K., Krause, K. H., 2007. The NOX family of ROSgenerating NADPH oxidases: Physiology and pathophysiology. Physiol. Rev. 87, 245-313.

Bhattacharya, P., Claesson, M., Bundschuh, J., Sracek, O., Fagerberg, J., Jacks, G., Martin, R. A., Storniolo, A. R., Thir, J. M., 2006. Distribution and mobility of arsenic in the Río Dulce alluvial aquifers in Santiago del Estero Province, Argentina. Sci. Total Environ. 358, 97-120.

Bodek, I., Lyman, W. J., Reehl, W. F., Rosenblatt, D. H., 1998. Environmental Inorganic Chemistry: Properties, Processes and Estimation Methods. Pergamon Press, USA.

British Geological Survey, Bangladesh Department of public health and engineering: Arsenic contamination of ground water in Bangladesh. Final Technical Report WC/00/19 (Eds: D.G. Kinniburgh and P.L. Smedley) Keyworth, UK, British geological survey. 2001.

Buettner, G. R., 1993. The pecking order of free radicals and antioxidants: lipid peroxidation, alpha-tocopherol, and ascorbate. Arch. Biochem. Biophys. 300, 535-543.

Cadenas, E., Davies, K. J., 2000. Mitochondrial free radical generation, oxidative stress, and aging. Free Radic. Biol. Med. 29, 222-230.

Cebrián, M. E., Albores, A., Aguilar, M., Blakely, E., 1983. 
Chronic arsenic poisoning in the north of Mexico. Hum. Toxicol. 2, 121-133.

Chakraborti, D., Mukherjee, S. C., Pati, S., Sengupta, M. K., Rahman, M. M., Chowdhury, U. K., Lodh, D., Chanda, C. R., Chakraborti, A. K., Basu, G. K., 2003. Arsenic groundwater contamination in Middle Ganga Plain, Bihar, India: a future danger? Environ. Health Perspect. 111, 1194-1201.

Chang, S. I., Jin, B., Youn, P., Park, C., Park, J. D., Ryu, D. Y., 2007. Arsenic-induced toxicity and the protective role of ascorbic acid in mouse testis. Toxicol. Appl. Pharmacol. 218, 196-203.

Chen, C. L., Hsu, L. I., Chiou, H. Y., 2004. Blackfoot Disease Study Group. Ingested arsenic, cigarette smoking, and lung cancer risk: a follow-up study in arseniasis-endemic areas in Taiwan. JAMA. 292, 2984-2990.

Chen, Y. C., Lin-Shiau, S. Y., Lin, J. K., 1998. Involvement of reactive oxygen species and caspase 3 activation in arsenite-induced apoptosis. J. Cell Physiol. 177, 324-333.

Del Razo, L. M., Quintanilla-Vega, B., Brambila-Colombres, E., Calderon-Aranda, E. S., Manno, M., Albores, A., 2001. Stress proteins induced by arsenic. Toxicol. Appl. Pharmacol. 177, 132-148.

Dhar, R. K., Biswas, B. K., Samanta, G., 1997. Groundwater arsenic calamity in Bangladesh. Curr. Sci. 73, 48-59.

Drobna, Z., Waters, S. B., Devesa, V., Harmon, A. W., Thomas, D. J., Styblo, M., 2005. Metabolism and toxicity of arsenic in human urothelial cells expressing rat arsenic (b3 oxidation state)-methyltransferase. Toxicol. Appl. Pharmacol. 207, 147-159.

Duker, A. A., Carranza, E. J., Hale, M., 2005. Arsenic geochemistry and health. Environ. Int. 31, 631-641.

EFSA. 2009. EFSA Panel on Contaminants in the Food Chain (CONTAM); Scientific Opinion on Arsenic in Food. EFSA Journal. 7, 198.

El-Benna, J., Dang, P. M., Gougerot-Pocidalo, M. A., Elbim, C., 2005. Phagocyte NADPH oxidase: A multicomponent enzyme essential for host defenses. Arch. Immunol. Ther. Exp. (Warsz). 53, 199-206.

Evans, J. L., Goldfine, I. D., Maddux, B. A., Grodsky, G. M., 2002. Oxidative stress and stress-activated signaling pathways: A unifying hypothesis of type 2 diabetes. Endocr. Rev. 23, 599-622.

Fattorini, D., Notti, A., Regoli, F., 2006. Characterization of arsenic content in marine organisms from temperate, tropical, and polar environments. Chem. Ecol. 22, 405414.

Fattorini, D., Regoli, F., 2004. Arsenic speciation in tissues of the Mediterranean polychaete Sabella spallanzanii. Environ. Toxicol. Chem. 23, 1881-1887.

Flora, S. J., Bhadauria, S., Pant, S. C., Dhaked, R. K., 2005. Arsenic induced blood and brain oxidative stress and its response to some thiol chelators in rats. Life Sci. 77, 2324-2337.

Flora, S. J., 2011. Arsenic-induced oxidative stress and its reversibility. Free Radic. Biol. Med. 12, 257-281.

Freeman, B. A., Crapo, J. D., 1982. Biology of disease: Free radicals and tissue injury. Lab INVEST. 47, 412-426.

Fridovich, I., 1984. Overview: Biological sources of $\mathrm{O}_{2-}$. Methods Enzymol. 105, 59-61.

Geiszinger, A. E., Goessler, W., Francesconi, K. A., 2002. The marine polychaete Arenicola marina: its unusual arsenic compound pattern and its uptake of arsenate from seawater. Mar. Environ. Res. 53, 37-50.

Ghosh, M. K., Mukhopadhyay, M., Chatterjee, I. B., 1997. NADPH-initiated cytochrome P450-dependent free ironindependent microsomal lipid peroxidation: specific prevention by ascorbic acid. Mol. Cell Biochem. 166, 3544.

Gurr, J. R., Liu, F., Lynn, S., Jan, K. Y., 1998. Calciumdependent nitric oxide production is involved in arseniteinduced micronuclei. Mutat. Res. 416, 137-148.

Guyton, K. Z., Kensler, T. W., 1993. Oxidative mechanisms in carcinogenesis. Br. Med. Bull. 49, 523-544.

Hall, A. H., 2002. Chronic arsenic poisoning. Toxicol Lett. $128,69-72$.

Halliwell, B., Gutteridge, J. M. C., 1989. Free Radicals in Biology and Medicine. Clarendon Press, Oxford, UK. 2.

Hassan, M. M., Atkins, P. J., Dunn, C. E., 2003. The spatial pattern of risk from arsenic poisoning: a Bangladesh case study. J. Environ. Sci. Health A: Tox. Hazard Subst. Environ. Eng. 38, 1-24.

Hsueh, Y. M., Wu, W. L., Huang, Y. L., Chiou, H. Y., Tseng, C. H., Chen, C. J., 1998. Low serum carotene level and increased risk of ischemic heart disease related to longterm arsenic exposure. Atherosclerosis. 141, 249-257.

IARC, 2012. A Review of Human Carcinogens: Arsenic, Metals, Fibres, and Dusts. Geneva, Switzerland: World Health Organization. 100C.

IARC, 2004. IARC Monograph on Evaluating Carcinogenesis Risks in Humans. Some drinking-water disinfectants and contaminants, including arsenic. World Health Organization, Geneva, Switzerland. 84, 1-477.

Integrated Risk Information Service (IRIS), 1997. U.S. Environmental Protection Agency. IRIS substance file: arsenic, inorganic. Web page http://www.epa.gov/ ngispgm3 /iris/subst/0278.htm. March, 1997.

Ito, H., Okamoto, K., Kato, K., 1998. Enhancement of expression of stress proteins by agents that lower the levels of glutathione in cells. Biochim Biophys Acta. 1397, 223-230.

Ivanov, I., Saam, J., Kuhn, H., Holzhutter, H. G., 2005. Dual role of oxygen during lipoxygenase reactions. FEBS J. 272, 2523-2535.

Judge, A. R., Dodd, S. L., 2004. Xanthine oxidase and activated neutrophils cause oxidative damage to skeletal muscle after contractile claudication. Am. J. Physiol. Heart. Circ. Physiol. 286, H252-H256.

Kam, P. C., Ferch, N. I., 2000. Apoptosis: mechanisms and clinical implications. Anaesthesia. 55, 1081-1093.

Karim, M. M., 2000. Arsenic in groundwater and health problems in Bangladesh. Water Res. 34, 304-310.

Kinniburgh, D. G., Smedley, P. L., 2001. Arsenic Contamination of Ground Water in Bangladesh. British 
Geological Survey. 2.

Kitchin, K. T., 2001. Recent advances in arsenic carcinogenesis: mode of action, animal model system and methylated arsenic metabolites. Toxicol. Appl. Pharmacol. $172,249-261$.

Klebanoff, S. J., 2005. Myeloperoxidase: Friend and foe. J. Leukoc. Biol. 77, 598-625.

Ko, R. J., 1999. Causes, epidemiology, and clinical evaluation of suspected herbal poisoning. J. Toxicol. Clin. Toxicol. 37, 697-708.

Kobayashi, Y., Cui, X., Hirano, S., 2005. Stability of arsenic metabolites, arsenic triglutathione $\left[\mathrm{As}(\mathrm{GS})_{3}\right]$ and methylarsenic diglutathione $\left[\mathrm{CH}_{3} \mathrm{As}(\mathrm{GS})_{2}\right]$, in rat bile. Toxicology. 211, 115-123.

Lambeth, J. D., 2004. NOX enzymes and the biology of reactive oxygen. Nat. Rev. Immunol. 4, 181-189.

Lamm, S. H., Engel, A., Penn, C. A., Chen, R., Feinleib, M., 2006. Arsenic cancer risk confounder in southwest Taiwan data set. Environ. Health Perspect. 114, 10771082.

Lynn, S., Gurr, J. R., Lai, H. T., Jan, K. Y., 2000. NADH oxidase activation is involved in arsenite-induced oxidative DNA damage in human vascular smooth muscle cells. Circ. Res. 86, 514-519.

Mandal, B. K., Suzuki, K. T., 2002. Arsenic round the world: A review. Talanta. 58, 201-235.

Maritim, A. C., Sanders, R. A., Watkins, J. B., 2003. Diabetes, oxidative stress, and antioxidants: a review. J. Biochem. Mol. Toxicol. 17, 24-38.

Nordenson, I., Beckman, L., 1991. Is the genotoxic effect of arsenic mediated by oxygen free radicals? Hum. Hered. 41, 71-73.

Novick, S. C., Warrell, R. P., 2000. Arsenicals in hematologic cancers. Semin. Oncol. 27, 495-501.

Oremland, R. S., Stolz, J. F., Hollibaugh, J. T., 2004. The microbial arsenic cycle in Mono Lake, California. FEMS Microbiol. Ecol. 48, 15-27.

Peters, S. C., Blum, J., Klaue, B., Karagas, M. R., 1999. Arsenic occurrence in New Hampshire groundwater. Environ. Sci. Technol. 33, 1328-1333.

Petrick, J. S., Jagadish, B., Mash, E. A., Aposhian, H. V., 2001. Monomethyl arsonous acid (MMA(III)) and arsenite: $\mathrm{LD}(50)$ in hamsters and in vitro inhibition of pyruvate dehydrogenase. Chem. Res. Toxicol. 14, 651656.

Ramos, O., Carrizales, L., Yanez, L., Mejia, J., Batres, L., Ortiz, D., Díaz-Barriga, F., 1995. Arsenic increased lipid peroxidation in rat tissues by a mechanism independent of glutathione levels. Environ. Health Perspect. 103, 85-88.

Sakurai, T., Ochiai, M., Kojima, C., Ohta, T., T., Sakurai, M.H., Takada, N.O., Qu, W., Wallkes, M.P., Himeno, S., Fujiwara, K., 2005. Preventive mechanism of cellular glutathione in monomethylarsonic acid-induced cytolethality. Toxicol. Appl. Pharmacol. 206, 54-65.

Sampayo-Reyes, A., Zakharyan, R. A., 2006. Inhibition of human glutathione S-transferase omega by tocopherol succinate. Biomed. Pharmacother. 60, 238-244.
Sancha, A., 2000. Removal of arsenic from drinking water supplies: Chile experience. Water Supply. 18, 621-625.

Santra, A., Dasgupta, J., De, B. K., Roy, B., Guha, Mazumder, D. N., 1999. Hepatic manifestations in chronic arsenic toxicity. Indian J. Gastroenterol. 18, 152-155.

Shila, S., Subathra, M., Devi, M. A., Panneerselvam, C., 2005. Arsenic intoxication- induced reduction of glutathione level and of the activity of related enzymes in rat brain regions: reversal by DL-alpha-lipoic acid. Arch. Toxicol. 79, 140-146.

Shrestha, R. R., 2003. Groundwater arsenic contamination, its health impact and mitigation program in Nepal. $\mathrm{J}$. Environ. Sci. Health. Part A-Toxic/Hazardous Subst. Environ. Eng. 38, 185-200.

Smedley, P. L., Kinniburgh, D. G., 2002. A review of the source, behaviour and distribution of arsenic in natural waters. Appl. Geochem. 17, 517-568.

Smith, A., Arroyo, A., Mazumder, G., Kosnett, M., Hernandez, A., Beeris, M., Smith, M., Moore, L., 2000. Arsenic-induced skin lesions among Atacameño people in northern Chile despite good nutrition and centuries of exposure. Environ. Health Perspect. 108, 617-620.

Steinmaus, C., Bates, M. N., Yuan, Y., Kalman, D., Atallah, R., Rey, O. A., Biggs, M. L., Hopenhayn, C., Moore, L. E., Hoang, B. K., Smith, A. H., 2006. Arsenic methylation and bladder cancer risk in case-control studies in Argentina and the United States. J. Occup. Environ. Med. 48, 478-488.

Tatoyan, A., Giulivi, C., 1998. Purification and characterization of a nitric-oxide synthase from rat liver mitochondria. J. Biol. Chem. 273, 11044-11048.

Thomas, D. J., Styblo, M., Lin, S., 2001. The cellular metabolism and systemic toxicity of arsenic. Toxicol. Appl. Pharmacol. 176, 127-144.

Thomas, D. J., Waters, S. B., Styblo, M., 2004. Elucidating the pathway for arsenic methylation. Toxicol. Appl. Pharmacol. 198, 319-326.

Tokar, E. J., Qu, W., Waalkes, M. P., 2011. Arsenic, stem cells, and the developmental basisof adult cancer. Toxicol. Sci. 120, 192-203.

Tolbert, N. E., Essner, E., 1981. Microbodies: peroxisomes and glyoxysomes. J. Cell Biol. 91, 271-283.

Townsend, D. M., Tew, K. D., 2003. The role of glutathione$\mathrm{S}$-transferase in anti-cancer drug resistance. Oncogene. 22, 7369-7375.

Tseng, C. H., 2004. The potential biological mechanisms of arsenic-induced diabetes mellitus. Toxicol Appl Pharmacol. 197, 67-83.

USPHS, Toxicological profile for arsenic. Washington, DC: US Public Health Servia. 1989.

Vahter, M., 1994. Species Differences in the Metabolism of Arsenic Compounds. Applied Organometallic Chem. 8, 175-182.

Waugh, J. L. T., Parker, S. P., Weil, J., Richman, B., 1982. McGraw-Hill Encyclopedia of Science and Technology. $5^{\text {th }}$ Edn. Vol. 1. McGraw-Hill, New York. pp.715-718.

WHO, 2003. United Nations Synthesis Report on Arsenic in 
Drinking Water.

Winship, K. A., 1984. Toxicity of inorganic arsenic salts. Adverse Drug React Acute Poisoning Rev. 3, 129-160.

Wyatt, C. J., Fimbres, C., Romo, L., Mendez, R. O., Grijalva, M., 1998. Incidence of heavy metal contamination in water supplies in northern Mexico. Environ. Res. 76, 114119.

Xia, Y., Liu, J., 2004. An overview on chronic arsenism via drinking water in PR China. Toxicol. 198, 25-29.

Yamanaka, K., Hayashi, H., Tachikawa, M., Kato, K., Hasegawa, A., Oku, N., Okada, S., Metabolic methylation is a possible genotoxicity-enhancing process of inorganic arsenics. Mutat. Res. 394, 95-101.
Yamanaka, K., Okada, S., 1994. Induction of lung-specific DNA damage by metabolically methylated arsenics via the production of free radicals. Environ. Health Perspect. 102, 37-40.

Yeh, S., How, S. W., Lin, C. S., 1968. Arsenical cancer of skin. Histologic study with special reference to Bowen's disease. Cancer. 21, 312-339.

Zakharyan, R. A., Ayala-Fierro, F., Cullen, W. R., Carter, D. M., Aposhian, H. V., 1999. Enzymatic methylation of arsenic compounds. VII. Monomethylarsonous acid (MMAIII) is the substrate for MMA methyltransferase of rabbit liver and human hepatocytes. Toxicol. Appl. Pharmacol. 158, 9-15.

\section{How to cite this article:}

Giri, A., Bharti, V. K., Angmo, K., Kalia, S., Vivek, P., Kumar, B., 2016. Arsenic and it's adjuvantic role on oxidative stress in animals: A brief overview. Int. J. Curr. Res. Biosci. Plant Biol. 3(12), 105-114.

doi: http://dx.doi.org/10.20546/ijcrbp.2016.312.013 